Article

\title{
The Impact on Antioxidant Enzyme Activity and Related Gene Expression Following Adult Zebrafish (Danio rerio) Exposure to Dimethyl Phthalate
}

\author{
Bailin Cong ${ }^{1, \dagger}$, Cong Liu ${ }^{2, \dagger}$, Lujie Wang ${ }^{2}$ and Yingmei Chai ${ }^{2, *}$ \\ 1 The First Institute of Oceanography, Ministry of Natural Resources, Qingdao 266061, China; biolin@fio.org.cn \\ 2 Department of Marine Science, Marine College, Shandong University (Weihai), Weihai 264209, China; \\ excong@163.com (C.L.); toodloo@126.com (L.W.) \\ * Correspondence: chaiyingmei@sdu.edu.cn; Tel.: +86-631-5688303 \\ + These authors contributed equally to this work.
}

Received: 7 April 2020; Accepted: 15 April 2020; Published: 20 April 2020

check for updates

Simple Summary: Dimethyl phthalate (DMP) is a widespread environmental contaminant and its toxicological effects on fish have not been adequately examined. Our present study clearly showed that a high concentration induced oxidative damage in zebrafish, which proved the molecular regulation due to the negative effects of DMP, along with the physical damage in zebrafish. We also found that antioxidant enzymes might be used as appropriate biochemical markers for the toxic identification of DMP.

\begin{abstract}
Dimethyl phthalate (DMP) is a widespread environmental contaminant that poses potential toxicity risks for animals and humans. However, the toxicological effects of DMP on fish have not been adequately examined. In this study, the acute toxicity, oxidative damage, antioxidant enzyme activities, and relative gene expression patterns were investigated in the liver of adult zebrafish (Danio rerio) exposed to DMP. We found that the lethal concentration ( $\left.\mathrm{LC}_{50}\right)$ of DMP for zebrafish after $96 \mathrm{~h}$ of exposure was $45.8 \mathrm{mg} / \mathrm{L}$. The zebrafish that were exposed to low, medium and high concentrations of DMP $(0.5,4.6$, and $22.9 \mathrm{mg} / \mathrm{L}$, respectively) for $96 \mathrm{~h}$ had an increased malondialdehyde (MDA) content and a lower antioxidant capacity compared with the control solvent group. The total superoxide dismutase (SOD) activity was significantly higher than $0 \mathrm{~h}$ after initial exposure for $24 \mathrm{~h}$ at low concentrations, and then decreased at high concentrations after exposure for $96 \mathrm{~h}$. The catalase (CAT) and glutathione S-transferase (GST) activities were significantly reduced after $96 \mathrm{~h}$ of exposure to high concentrations of DMP, with the up- or down-regulation of the related transcriptional expression. These findings indicated that DMP could cause physiological effects in zebrafish by disturbing the expression levels of antioxidant enzymes. These results might contribute to the identification of biomarkers to monitor phthalate pollution.
\end{abstract}

Keywords: zebrafish; DMP; antioxidant enzyme activity; gene expression

\section{Introduction}

Phthalic acid esters (PAEs) are a class of ubiquitous chemicals in the environment, widely used as plasticizers for plastics in many household and industrial products [1-3]. Low molecular weight dimethyl phthalate (DMP) is one of the most common and extensively used PAEs that has been frequently reported in various environmental samples, including marine water, freshwater, sediment, soil, fatty foods and cosmetics, and the concentrations of DMP in landfill leachate has reached $300 \mathrm{mg} / \mathrm{L}[4,5]$. The frequency of DMP contamination has been detected to be $37 \%$ in common food samples from a market in Albany, New York, and significantly higher in China [6,7]. Due to its wide 
applications in many kinds of products, such as perfumes, paints, waxes, pharmaceutical products, insecticide materials, adhesives, printing inks, coatings and cosmetics, DMP has been designated as an environmental priority organic pollutant by many regulators, such as the United States, the European Union and China [8,9]. Because of its simplicity and relative stability under natural environmental conditions, its half-life is approximately 3 years, and its highest solubility in water is $4500 \mathrm{mg} / \mathrm{L}$ at $25^{\circ} \mathrm{C}$. DMP has been recognized as posing a potential threat to the environment and human health [10]. The toxicological properties of PAEs include the hepatotoxic, reproductive/developmental, endocrine, and neurological effects in humans and animals [11-14], and the acute exposure via inhalation leads to irritation of the eyes, nose, and throat in humans and animals $[15,16]$. Short- to intermediate-term exposure induces decrements in body weight gain, changes in hemoglobin and increases in absolute and relative liver weights [17].

Based on standard ecotoxicity tests, employing more detectable responses to the expression levels of antioxidant enzyme genes and enzymatic activities may be used as reliable biochemical markers for the toxicity evaluation of PAE pollutants [18-21]. The increasing of oxidative stress can be induced by a number of phthalates via influencing antioxidant enzyme activities in some organisms, including fish [18-22]. Zhang et al. (2014) discovered that low concentrations of benzyl butyl phthalate (BBP) could stimulate superoxide dismutase (SOD) activity, while high concentrations inhibited this activity and the mRNA levels of SOD inhibition decreased and then increased in the muscles of zebrafish after 7 days of exposure [23]. Yang et al. (2018) demonstrated that di (2-ethylhexyl) phthalate (DEHP) exposure at 20,100 and $200 \mu \mathrm{g} / \mathrm{L}$ over 21 days suppressed the activity and transcriptional expression of the antioxidant enzymes SOD, catalase (CAT) and glutathione s-transferase (GST) in the fry of medaka fish [24]. More recently, Qu et al. (2015) and Zheng et al. (2013) reported that in Carassius auratus, when the fish were injected with 17 different PAEs at a concentration of $10 \mathrm{mg} / \mathrm{kg}$ for several days, respectively, the activities of antioxidant enzymes (SOD and CAT) were inhibited by DMP with an increasing treatment time $[19,25]$. These findings suggest that subacute concentrations of PAEs, including DMP, can induce oxidative stress in fish.

To date, research on the toxicological effects of DMP in humans and aquatic animals is still limited. Zebrafish are commonly used as a promising model organism for studies on the toxicity of pollutants due to their high homology with vertebrates [26,27]. The present study investigated the effects of DMP on the amount of malondialdehyde (MDA), antioxidant enzymatic activities and mRNA levels in the livers of zebrafish in batch mode under controlled conditions. This information is intended to find useful biomarkers of DMP pollution.

\section{Materials and Methods}

\subsection{Experimental Materials}

Four-month-old zebrafish (a total of 500) were obtained from a local fish dealer (Weihai, China) and reared in $500 \mathrm{~L}$ glass tanks (containing $400 \mathrm{~L}$ of dechlorinated and charcoal-filtered tap water) for 2 weeks at $25 \pm 1^{\circ} \mathrm{C}$, pH $7.2 \pm 0.3$, and a dissolved oxygen content of $6.00 \mathrm{ppm}$ with $14 \mathrm{~h}$ light/10 h dark cycles. The fish were fed 2 times a day with tropical flake food. Before DMP exposure, 20 fish were acclimated in 20 L glass tanks for 1 week. All experiments were performed under the approval of the Committee on Animal Care and Use and the Committee on the Ethics of Animal Experiments of Shandong University at Weihai. All of the zebrafish collections and the anatomy experiments were conducted in accordance with the "Guidelines for Experimental Animals" of the Ministry of Science and Technology (Beijing, China; No. [2006] 398, 30 September 2006). Zebrafish hypothermic shock was performed in an ice bath (5 parts ice to 1 part system water at a constant temperature of $2-4{ }^{\circ} \mathrm{C}$ ) [28].

DMP (CAS No. 131-11-3) was purchased from the Beijing Solarbio Science and Technology Co. Ltd. (Beijing, China). DMP for the exposure experiments was solubilized in acetone and the chemicals used were of analytical grade [29]. 


\subsection{Exposure Experiments and Sample Collection}

A toxicity test to assess the $96 \mathrm{~h} \mathrm{LC}_{50}$ value of DMP in zebrafish was performed in a laboratory system according to Organisation for Economic Co-operation and Development (OECD) guidelines [30]. The initial concentrations of DMP used were 25, 50, 100, 150, and $200 \mathrm{mg} / \mathrm{L}$. Ten zebrafish in each experimental tank $(20 \mathrm{~L})$ were introduced for $96 \mathrm{~h}$ based on a range-finding test prior to the experiment. The blank control and solvent control received $0.004 \%$ acetone $(\mathrm{v} / \mathrm{v})$, the same concentration used in the test groups which contained a series of concentrations $(25,50,100,150$, and $200 \mathrm{mg} / \mathrm{L} \mathrm{DMP})$ [31]. For each treatment, 5 replicates with 10 fish each were conducted (blank control, solvent control, plus DMP). The test fish were not fed, and the behavioral and morphological features were checked by visual analyses.

On the basis of the zebrafish mortality in each tank, acute toxicity was expressed as the $\mathrm{LC}_{50}$ of DMP, which was calculated by using the probit analysis method [32].

After the $\mathrm{LC}_{50}$ value was determined, the zebrafish were exposed to subacute toxic concentrations of DMP $(0.5,4.6$, and $22.9 \mathrm{mg} / \mathrm{L})$, and parallel blank control and solvent control groups were used in the exposure experiments. Each concentration in the DMP groups had 4 replicates with 80 fish each, and the control groups had the same replicates. For each time endpoint (24, 48, and $96 \mathrm{~h})$, liver samples were dissected from 20 living fish $(2.5 \pm 0.3 \mathrm{~cm}$ and weight $0.22 \pm 0.05 \mathrm{~g})$ in each group via a stereomicroscope washing twice with phosphate buffer saline (PBS) on an ice-cold plate and divided into 2 samples: 15 individuals were used to assay MDA and antioxidant enzyme activity, and 5 individuals were used for real-time polymerase chain reaction (RT-PCR).

\subsection{Biochemical Assays}

Each liver sample was homogenized in a homogenizer in ice-cold buffer $(0.1 \mathrm{M}$ Tris- $\mathrm{HCl}$, $0.1 \mathrm{mM}$-EDTA, $0.1 \%$ Triton X-100 (v/v), pH 7.8). The homogenates were centrifuged, and the supernatants were collected. The supernatants were used for biochemical parameter measurements. The protein content, MDA, total antioxidant capacity (T-AOC), and the activities of the antioxidant enzymes were analyzed using kits (Nanjing Jiancheng Bioengineering Institute, Nanjing, China) according to the manufacturer's instructions. The quantity of protein was measured by the Bradford method using bovine serum albumin as a standard [33]. The T-AOC was detected by the reducing ability of ferric ions to ferrous ions and expressed as $\mathrm{U} / \mathrm{mg}$ protein (nmol of ferric ions reduced per $\mathrm{min} / \mathrm{mg}$ protein). The MDA levels were measured by the conversion of thiobarbituric acid to reactive substances, which had a high absorbance at $532 \mathrm{~nm}$. The MDA concentrations were expressed as $\mathrm{nmol} / \mathrm{mg}$ protein.

The total SOD activity was measured by the nitro blue tetrazolium (NBT) method at $560 \mathrm{~nm}$ [34]. The enzymatic activity was calculated as U/mg protein. One unit of SOD was defined as the amount of sample required to inhibit the rate of reduction of NBT by $50 \%$. The CAT activity was detected by the decrease in hydrogen peroxide radical $\left(\mathrm{H}_{2} \mathrm{O}_{2}\right)$ concentration at $240 \mathrm{~nm}$ [35]. The CAT activity (1 U) was expressed as $1 \mathrm{mmol}$ of decomposed hydrogen peroxide per second per $\mathrm{mg}$ of protein. The glutathione S-transferase (GST) activity was determined by 1-chloro-2, 4-dinitrobenzene colorimetry, and the absorbance was measured at $340 \mathrm{~nm}$ for $5 \mathrm{~min}$. The GST activity was expressed as the number of $\mu \mathrm{mol}$ in $1 \mathrm{minute}$ per $\mathrm{mg}$ of protein ( $\mu \mathrm{mol} / \mathrm{mg}$ protein $/ \mathrm{min})$.

\subsection{Molecular Studies}

The total RNA was extracted from the liver tissues in each treatment group by using TRIzol reagent according to the manufacturer's protocol (Invitrogen, Carlsbad, CA, USA). First-strand cDNA was synthesized by the use of the SMART cDNA method (BD Biosciences-Clontech, Palo Alto, CA, USA). Finally, quantitative RT-PCR (RT-PCR) was performed on a 7300 real-time system (Applied Biosystems, Foster City, CA, USA). The PCR mix (Takara, TB Green ${ }^{\mathrm{TM}}$ Premix Ex Taq II, Chiryu Shi, Japan) was denatured at $94{ }^{\circ} \mathrm{C}$ for $3 \mathrm{~min}$, followed by 40 cycles of amplification $\left(94{ }^{\circ} \mathrm{C}\right.$ for $15 \mathrm{~s}, 58^{\circ} \mathrm{C}$ for 
$20 \mathrm{~s}$, and $72{ }^{\circ} \mathrm{C}$ for $20 \mathrm{~s}$ ). All reactions were repeated in triplicate for the RT-PCR analysis. Beta-actin was used as the housekeeping gene, and the changes in the abundances of transcripts of each target gene were expressed as its ratio to the expression of the reference gene (Table 1). A significant difference was accepted at $p<0.05$. The reaction of each template was performed in triplicate. The relative gene expression level was calculated using the comparative $\mathrm{Ct}$ (2- $\Delta \Delta \mathrm{Ct})$ method [36]. The types of tested SOD, CAT and GST gene were superoxide dismutase 1, catalase transcript variant X2 and glutathione S-transferase pi 1, respectively.

Table 1. Primer sequences used for real-time-polymerase chain reaction (PCR).

\begin{tabular}{|c|c|c|c|c|}
\hline Primer & Primer Sequence $\left(5^{\prime}-3^{\prime}\right)$ & $\begin{array}{c}\text { Annealing } \\
\text { Temperature (Tm) }\end{array}$ & $\begin{array}{c}\text { Product } \\
\text { Length (bp) }\end{array}$ & $\begin{array}{c}\text { Amplification } \\
\text { Efficiency }\end{array}$ \\
\hline $\begin{array}{l}\text { superoxide dismutase } \\
(S O D) \text { primer-F }\end{array}$ & TCCGCACTTCAACCCTCA & 58.44 & \multirow{2}{*}{215} & \multirow{2}{*}{$97.0 \%$} \\
\hline SOD primer-R & ССТСАTTGCСАСССТТСС & 57.66 & & \\
\hline catalase (CAT) primer-F & TACCAGTCAACTGCCCGTAC & 59.40 & \multirow{2}{*}{145} & \multirow[b]{2}{*}{$96.5 \%$} \\
\hline CAT primer-R & GACTCAAGGAAGCGTGGC & 58.43 & & \\
\hline glutathione S-transferase & ССААССАССТСАААТGСТ & 55.09 & \multirow[b]{2}{*}{150} & \multirow[b]{2}{*}{$98.1 \%$} \\
\hline $\begin{array}{l}(G S T) \text { primer-F } \\
\text { GST primer-R }\end{array}$ & ACGGGAAAGAGTCCAGACAG & 59.03 & & \\
\hline Beta-actin primer-F & CGAGCAGGAGATGGGAACC & 59.86 & \multirow[b]{2}{*}{214} & \multirow{2}{*}{$99.5 \%$} \\
\hline Beta-actin primer- $\mathrm{R}$ & CAACGGAAACGCTCATTGC & 58.29 & & \\
\hline
\end{tabular}

\subsection{Statistical Analyses}

The statistical analyses were performed with SPSS 19.0 and Excel 2007 software. The experimental data were expressed as the mean \pm standard deviation. Student's $t$-test was used to examine the differences between the treatment groups and control groups (the significance level was $p<0.05$ ).

\section{Results}

\subsection{Effects of DMP on Zebrafish Survival}

The mortality of the zebrafish treated with different concentrations of DMP was seen to increase in a dose-dependent manner (Figure 1). Figure 1 shows survivorship curves for DMP treatment in the zebrafish at various concentrations in water after $96 \mathrm{~h}$ of exposure. There was only $20 \%$ mortality in the $25 \mathrm{mg} / \mathrm{L}$ group within $96 \mathrm{~h}$, and the remaining fish survived. In the $100 \mathrm{mg} / \mathrm{L}$ DMP-treated group, there was $80 \%$ mortality in $96 \mathrm{~h}$. There was $100 \%$ mortality in the $200 \mathrm{mg} / \mathrm{L}$ group, and mortality occurred within $96 \mathrm{~h}$. Therefore, the $\mathrm{LC}_{50}$ value of DMP for zebrafish was calculated to be $45.8 \mathrm{mg} / \mathrm{L}$. The zebrafish (>80\%) exposed in the experimental tanks containing 100 to $200 \mathrm{mg} / \mathrm{L}$ showed less movement and body shape changes compared to the solvent control after $24 \mathrm{~h}$ of incubation. After $72 \mathrm{~h}$ of incubation, $>90 \%$ of these zebrafish floated on the surface of the water and died. More than $90 \%$ of the zebrafish died within $48 \mathrm{~h}$ of incubation in $200 \mathrm{mg} / \mathrm{L} \mathrm{DMP}$. In contrast, all the control zebrafish survived. 


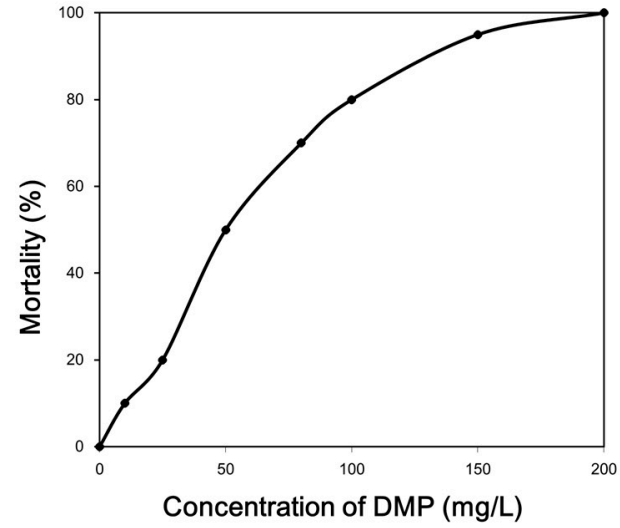

(a)

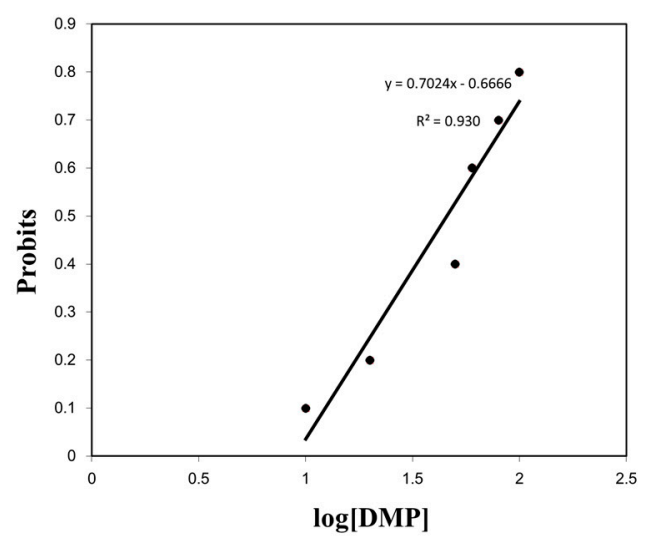

(b)

Figure 1. Dose-response relationships after $96 \mathrm{~h}$ of exposure for dimethyl phthalate (DMP): (a) mortality of zebrafish treated with different concentrations of DMP; (b) probit models at different concentrations of DMP for calculation of the $\mathrm{LC}_{50}$.

\subsection{Effect of DMP on Oxidative Stress in Zebrafish}

To determine the effects of DMP on lipid peroxidation, the zebrafish were exposed to three sublethal concentrations of DMP $(0.5,4.6$, and $22.9 \mathrm{mg} / \mathrm{L})$ for 24,48 and $96 \mathrm{~h}$ (Figure 2). As shown in Figure 2, the MDA content was elevated in the low concentration experimental group at $24 \mathrm{~h}$, levelled off after $48 \mathrm{~h}(p<0.05$, Figure 2$)$, and increased in the medium and high concentration treatment groups at all time points.

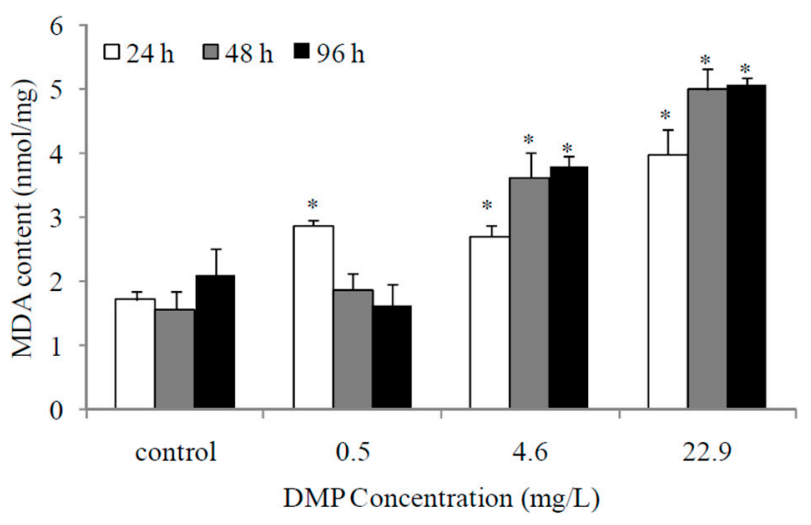

Figure 2. DMP-induced lipid peroxidation levels in zebrafish. Adult fish were exposed to $0.5,4.6$ and $22.9 \mathrm{mg} / \mathrm{L} \mathrm{DMP}$ for 24, 48, and $96 \mathrm{~h}$. Error bars represent the standard deviation. Significant differences from the control are indicated by an asterisk, which is based on Student's $t$-test $(p<0.05)$.

As shown in Figure 3, the T-AOC values of fish after low concentrations of DMP treatment increased significantly at $24 \mathrm{~h}$ and then gradually decreased. However, the fish exposed to high concentrations of DMP showed an obvious reduction in the T-AOC values.

The activity levels of the primary antioxidant enzymes SOD, CAT, and GST after exposure to DMP are shown in Figure 4a-c. Upon treatment with a low concentration of DMP for $24 \mathrm{~h}$, there was an increased level in the SOD activity and no obvious changes in the levels of CAT and GST activity; after $48 \mathrm{~h}$, the SOD activity was reduced and the GST activity increased significantly. The treatment of fish with high concentrations of DMP showed a decline in SOD and CAT activities at $24 \mathrm{~h}$, and GST activity increased. After $96 \mathrm{~h}$ of exposure to high concentrations of DMP, the activities of SOD, CAT, and GST all decreased gradually with time and were lower than the control groups (Figure $4 a-c)$. 


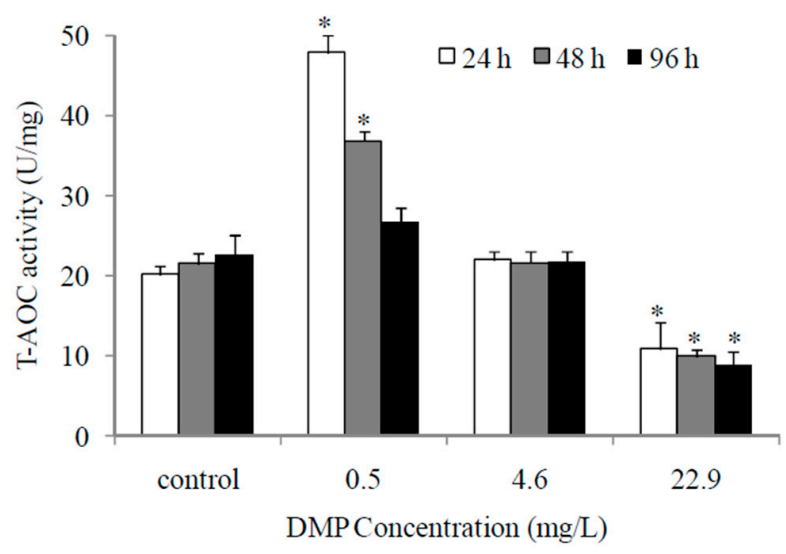

Figure 3. DMP-induced changes of total anti-occident capacity (T-AOC) in zebrafish. Adult fish were exposed to $0.5,4.6$ and $22.9 \mathrm{mg} / \mathrm{L} \mathrm{DMP}$ for 24,48 , and $96 \mathrm{~h}$. Statistical significance between experimental and control groups are indicated with asterisks: significance is based on Student's $t$-test $(p<0.05)$. The error bars represent the standard deviation $(n=5)$.



Figure 4. DMP-induced changes of antioxidant enzyme activity in zebrafish liver: (a) superoxide dismutase (SOD) activity; (b) catalse (CAT) activity; (c) glutathione s-transferese (GST) activity. Adult fish were exposed to $0.5,4.6$ and $22.9 \mathrm{mg} / \mathrm{L} \mathrm{DMP}$ for 24,48 , and $96 \mathrm{~h}$. Statistical significance between the experimental and control groups is indicated with an asterisk: $p<0.05$. The error bars represent the standard deviation $(n=5)$. 


\subsection{Effects of DMP on the Transcription of Related Antioxidant Enzymes}

The gene expression levels of the antioxidant enzymes, SOD, CAT and GST after DMP exposure were investigated (Figure $5 \mathrm{a}-\mathrm{c}$ ). The fish exposed to low, medium, and high concentrations of DMP for 24, 48, and $96 \mathrm{~h}$ showed significant up- or down-regulation in the gene expression levels of SOD, $C A T$ and GST. The gene expression of CAT after $48 \mathrm{~h}$ of DMP treatment was reduced significantly. Low concentrations of DMP showed no obvious change in CAT mRNA levels after $24 \mathrm{~h}$, but SOD and GST transcription increased notably after $48 \mathrm{~h}$. Medium and high concentrations of DMP resulted in the up-regulation of $S O D$ mRNA expression after 24 and $48 \mathrm{~h}$ followed by down-regulation of $S O D$ and GST expression after $96 \mathrm{~h}$.

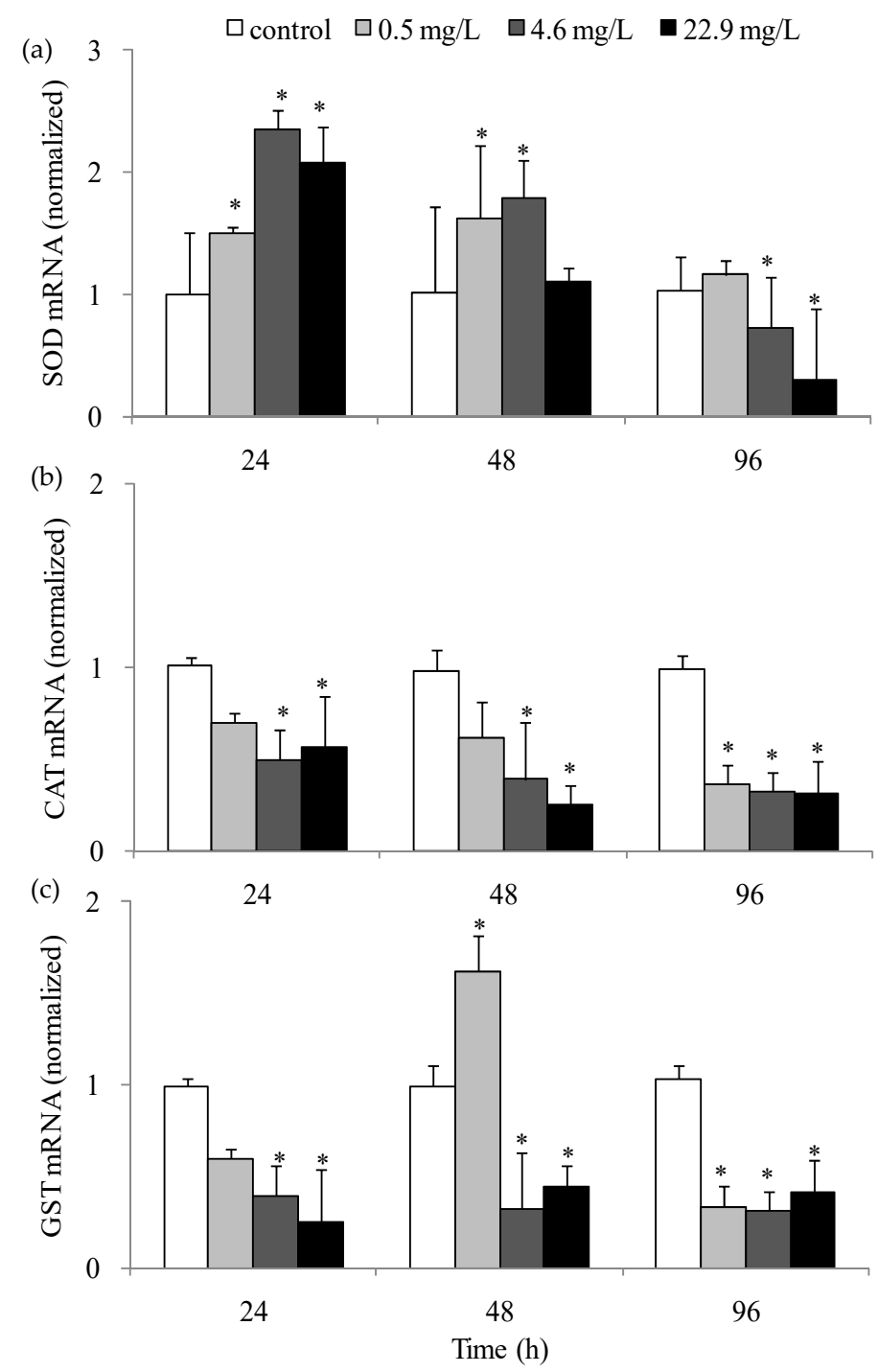

Figure 5. Gene expression level of antioxidant enzyme in zebrafish liver exposed to DMP: (a) the $S O D$ gene expression; (b) CAT gene expression; (c) GST gene expression. Adult fish were treated with 0.5, 4.6 and $22.9 \mathrm{mg} / \mathrm{L} \mathrm{DMP}$ for 24, 48, and $96 \mathrm{~h}$. Gene expression levels of significance compared to the control are marked with asterisks $(p<0.05)$. The error bars represent the standard deviation $(\mathrm{n}=5)$.

\section{Discussion}

PAEs have become global pollutants that contaminate water resources and affect aquatic organism health, including fish. The present study investigated the toxic effects of a low molecular weight phthalate, DMP, on zebrafish. In the present study, the $96 \mathrm{~h} \mathrm{LC}_{50}$ of DMP was found to be $45.8 \mathrm{mg} / \mathrm{L}$ in zebrafish. Similar results were obtained in a study of other fish species; the $\mathrm{LC}_{50}$ of DMP has been 
reported to be $50 \mathrm{mg} / \mathrm{L}$ for bluegills (Lepomis macrochirus), $55.8 \mathrm{mg} / \mathrm{L}$ for black molly (Poecilia sphenops), $56 \mathrm{mg} / \mathrm{L}$ for rainbow trout (Oncorhynchus mykiss), and $39 \mathrm{mg} / \mathrm{L}$ (flow through) and $121 \mathrm{mg} / \mathrm{L}$ (static) for fathead minnows (Pimephales promelas) [37-39]. Moreover, zebrafish embryos develop a low incidence of general dysmorphology at $1 \times 10^{-5}$ or $1 \times 10^{-4} \mathrm{M}$ DMP [40] The $\mathrm{LC}_{50}$ of DMP varies between 0.48 and $121 \mathrm{mg} / \mathrm{L}$ in aquatic fish species [41,42]. This is attributed to the experimental conditions and several other factors, such as different fish species, age, feeding habits, and sex.

Under the stress of exogenous factors (such as chemical contaminants), organisms will produce a lot of harmful free radicals, like superoxide radicals, hydrogen peroxide radicals and hydroxyl radicals. The accumulation of free radicals stimulates the organism to play the role of the antioxidant defense system to avoid biological damage [43]. However, when the generation rate of free radicals is faster than its elimination, organisms will be oxidatively damaged, including enzymes inactivation, DNA and cholesterol damage, and the peroxidation of unsaturated fats in the cell membrane. It will destroy the integrity of the cell membrane caused by undergoing lipid peroxidation [44]. Therefore, antioxidant defense is an important defense against the impact of environmental contaminants. The involvement of antioxidant enzymes (such as SOD, CAT, and GST) can protect cells from oxidant damage. Among antioxidant enzymes, SOD plays an important role in the first defense system that is involved in the detoxification of reactive oxygen free radicals and $\mathrm{H}_{2} \mathrm{O}_{2}$ [45]. CAT, another key antioxidant defense enzyme, is regarded as an important biomarker to estimate oxidative stress via alterations in activity, and GST plays a key role in detoxifying a variety of electrophilic substances into hydrophilic compounds as a second-phase detoxification enzyme and antioxidant [46-48]. MDA is a final important product of lipid peroxidation from oxidative stress, and analyzing its production can reflect damage to organisms [49]. As such, the degree of lipid peroxidation in an animal can be indirectly measured by MDA. In the present study, the MDA content in zebrafish showed an increasing trend at $24 \mathrm{~h}$ and a decreasing trend at $96 \mathrm{~h}$ upon exposure to low concentrations of DMP, and with high concentrations of DMP and prolonged exposure, MDA accumulated. This indicated that the antioxidant mechanism of the fish treated with low concentrations of DMP for $24 \mathrm{~h}$ can effectively eliminate oxidative damage. However, after $96 \mathrm{~h}$ of exposure to high concentrations of DMP, the oxidative damage induced by DMP became severe in fish.

T-AOC level is a comprehensive indicator to measure the function of the antioxidant systems. In this experiment, the highest activity of T-AOC enzyme was tested at a low concentration of DMP for $24 \mathrm{~h}$, while the lowest activity was tested at a high concentration for $96 \mathrm{~h}$. This suggests that zebrafish liver tissue has the highest antioxidant capacity under low concentration (24 h) DMP stress, but under high concentration DMP stress, the body is oxidatively damaged and the total antioxidant capacity decreases. Zhang et al. also reported that the highest activity of T-AOC in the liver of Carassius auratus was detected when exposed to $\mathrm{B}(\mathrm{a}) \mathrm{P}$. As the $\mathrm{B}(\mathrm{a}) \mathrm{P}$ concentration increases, T-AOC activity in the liver gradually decreases [50].

We found that the activity of SOD presented a rising trend at $24 \mathrm{~h}$ and a falling trend at $96 \mathrm{~h}$. This might be due to the increasing production of oxygen free radicals that correspondingly leads to increasing SOD activity under the stress of DMP. CAT activity was reduced at high concentrations due to excessive amounts of DMP enhancing the stress, which leads to the depletion of the CAT and SOD enzymes. Similarly, $48 \mathrm{~h}$ of exposure to low concentrations of DMP led to increased GST activity, which was later reduced at $96 \mathrm{~h}$. In a recent study, the effects of endocrine disrupting compounds on antioxidative balance were investigated in wildlife vertebrates [51]. Similar results were also observed in the livers of Carassius auratus injected intraperitoneally with 17 different phthalates at a concentration of $10 \mathrm{mg} / \mathrm{kg}$ for 10 days [25]. Many previous studies have shown that oxidative stress status is interrelated with pollutant exposure, which is a possible regulation of the toxicity of these chemicals [52-59].

In this study, SOD, CAT and GST enzyme activities in zebrafish liver were consistent with T-AOC, and the highest expression was detected at low concentrations of DMP contrast in the lowest under high concentrations of DMP stress. This shows that under the stress of DMP, the change pattern of 
antioxidant enzymes in zebrafish is consistent with its own antioxidant capacity, which indicates the level of environmental pollution and oxidative stress in the zebrafish and the key role of SOD, CAT and GST in the antioxidant defense system.

Changes in transcriptional levels are commonly used as the earliest and most sensitive biomarkers for physiological responses to environmental stress. Our results showed that DMP exposure down-regulated the expression levels of CAT and GST. These results are consistent with the enzymatic activity and T-AOC levels after exposure to DMP. Irrespective of the mechanism in zebrafish, the toxicity of DMP may lead to lower antioxidant enzyme activity and cause oxidative damage to the organism.

\section{Conclusions}

The present study clearly showed that a high concentration of DMP induced oxidative damage in zebrafish. We found that high or low antioxidant enzyme activity could affect the survival and health status of zebrafish and consequently cause increased fish mortality. This study also determined that DMP disturbed the gene expression levels of SOD, CAT, and GST; therefore, antioxidant enzymes might be used as appropriate biochemical markers for the toxic identification of DMP. Further studies are needed to elucidate whether exposure to plasticizers and alterations to particular isoforms of antioxidant enzymes are underlying factors of abnormality and malfunction in different systems of fish under long processes.

Author Contributions: Conceptualization, B.C. and Y.C.; methodology, Y.C.; software, C.L.; validation, B.C. and Y.C.; formal analysis, L.W.; investigation, B.C.; resources, B.C.; data curation, Y.C.; writing-original draft preparation, Y.C.; writing-review and editing, B.C.; visualization, C.L.; supervision, Y.C.; project administration, B.C.; funding acquisition, B.C. and Y.C. All authors have read and agreed to the published version of the manuscript.

Funding: This research was funded by Basic Scientific Fund for National Public Research Institutes 2018Q03, the Key Lab of Marine Bioactive Substance and Modern Analytical Technique, SOA (MBSMAT-2017-07) and the Chinese National Natural Science Foundation Grant No: 41006102 and The APC was funded by Basic Scientific Fund for National Public Research Institutes 2018Q03.

Conflicts of Interest: The authors declare no conflict of interest.

\section{References}

1. Net, S.; Sempéré, R.; Delmont, A.; Paluselli, A.; Ouddane, B. Occurrence, fate, behavior and ecotoxicological state of phthalates in different environmental matrices. Environ. Sci. Technol. 2015, 49, 4019-4035. [CrossRef] [PubMed]

2. Wittassek, M.; Koch, H.M.; Angerer, J.; Bruning, T. Assessing exposure to phthalates—the human biomonitoring approach. Mol. Nutr. Food Res. 2011, 55, 7-31. [CrossRef] [PubMed]

3. Zhang, L.; Liu, J.; Liu, H.; Wan, G.; Zhang, S. The occurrence and ecological risk assessment of phthalate esters (PAEs) in urban aquatic environments of China. Ecotoxicology 2015, 24, 967-984. [CrossRef] [PubMed]

4. Osman, B.; Ozer, E.T.; Demirbel, E.; Güçer, S.; Beşirli, N. Synthesis and characterization of L-tryptophan containing microbeads for removal of dimethyl phthalate from aqueous phase. Sep. Purif. Technol. 2013, 109, 40-47. [CrossRef]

5. Mersiowsky, L. Long-term fate of PVC products and their additives in landfills. Rog. Polym. Sci. 2002, 27, 2227-2277. [CrossRef]

6. Schecter, A.; Lorber, M.; Guo, Y.; Wu, Q.; Yun, S.H.; Kannan, K.; Hommel, M.; Imran, N.; Hynan, L.S.; Cheng, D.; et al. Phthalate concentrations and dietary exposure from food purchased in New York State. Environ. Health Perspect. 2013, 121, 473-494. [CrossRef]

7. Wang, W.; Leung, A.O.W.; Chu, L.H.; Wong, M.H. Phthalates contamination in China: Status, trends and human exposure-with an emphasis on oral intake. Environ. Pollut. 2018, 238, 771-782. [CrossRef]

8. European Union. Council Regulation (EC) No. 793/93 on the evaluation and control of the risks of existing substances. Off. J. Eur. Communities. 1993, 36, 1-7.

9. Appendix A to 40 CFR, Part 423-126 Priority Pollutants. Available online: https://www3.epa.gov/region1/ npdes/permits/generic/prioritypollutants.pdf (accessed on 16 December 2019). 
10. Stales, C.A.; Peterson, D.R.; Parkerton, T.F.; Adams, W.J. The Environmental Fate of Phthalate Esters: A Literature Review. Chemosphere 1997, 35, 667-749. [CrossRef]

11. Suzuki, Y.; Yoshinaga, J.; Mizumoto, Y.; Serizawa, S.; Shiraishi, H. Foetal exposure to phthalate esters and anogenital distance in male newborns. Int. J. Androl. 2012, 35, 236-244. [CrossRef]

12. Braun, J.M.; Sathyanarayana, S.; Hauser, R. Phthalate exposure and children's health. Curr. Opin. Pediatr. 2013, 25, 247-254. [CrossRef] [PubMed]

13. Chen, X.; Xu, S.; Tan, T.; Lee, S.T.; Cheng, S.H.; Lee, F.W.F.; Xu, S.J.L.; Ho, K.C. Toxicity and Estrogenic Endocrine Disrupting Activity of Phthalates and Their Mixtures. Int. J. Environ. Res. Public Health. 2014, 11, 3156-3168. [CrossRef] [PubMed]

14. Oehlmann, J.; Schulte-Oehlmann, U.; Kloas, W.; Jagnytsch, O.; Lutz, I.; Kusk, K.O.; Wollenberger, L.; Santos, E.M.; Paull, G.C.; Van Look, K.J.; et al. A critical analysis of the biological impacts of plasticizers on wildlife. Philos. Trans. R. Soc. Lond. B. Biol. Sci. 2009, 364, 2047-2062. [CrossRef] [PubMed]

15. Call, D.J.; Markee, T.P.; Geiger, D.L.; Brooke, L.T.; VandeVenter, F.A.; Cox, D.A.; Genisot, K.I.; Robillard, K.A.; Gorsuch, J.W.; Parkerton, T.F. An assessment of the toxicity of phthalate esters to freshwater benthos. 1. Aqueous exposures. Environ. Toxicol. Chem. 2001, 20, 1798-1804. [CrossRef] [PubMed]

16. Lyche, J.L.; Gutleb, A.C.; Bergman, A.; Eriksen, G.S.; Murk, A.J.; Ropstad, E.; Saunders, M.; Skaare, J.U. Reproductive and developmental toxicity of phthalates. J. Toxicol. Environ. Health B. Crit. Rev. 2009, 12, 225-249. [CrossRef]

17. Kumar, P. Role of Plastics on Human Health. Indian J. Pediatr. 2018, 85, 384-389. [CrossRef]

18. Zhao, X.; Gao, Y.; Qi, M. Toxicity of phthalate esters exposure to carp (Cyprinus carpio) and antioxidant response by biomarker. Ecotoxicology. 2014, 23, 626-632. [CrossRef]

19. Qu, R.; Feng, M.; Sun, P.; Wang, Z. A comparative study on antioxidant status combined with integrated biomarker response in Carassius auratus fish exposed to nine phthalates. Environ. Toxicol. 2015, 30, 1125-1134. [CrossRef]

20. Wang, G.; Wang, J.; Zhu, L.; Wang, J.; Li, H.; Zhang, Y.; Liu, W.; Gao, J. Oxidative Damage and Genetic Toxicity Induced by DBP in Earthworms (Eisenia fetida). Arch. Environ. Contam. Toxicol. 2018, 74, 527-538. [CrossRef]

21. Kondolot, M.; Ozmert, E.N.; Ascl, A.; Erkekoglu, P.n.; Oztop, D.B.; Gumus, H.; Kocer-Gumusel, B.; Yurdakok, K. Plasma phthalate and bisphenol a levels and oxidant-antioxidant status in autistic children. Environ. Toxicol. Pharmacol. 2016, 43, 149-158. [CrossRef]

22. Kang, J.C.; Jee, J.-H.; Koo, J.-G.; Keum, Y.-H.; Jo, S.-G.; Park, K.H. Anti-oxidative status and hepatic enzymes following acute administration of diethyl phthalate in olive flounder Paralichthys olivaceus, a marine culture fish. Ecotoxicol. Environ. Saf. 2010, 73, 1149-1455. [CrossRef] [PubMed]

23. Zhang, C.; Yang, X.; He, Z.; Zhong, Q.; Guo, J.; Hu, X.J.; Xiong, L.; Liu, D. Influence of BBP exposure on nervous system and antioxidant system in zebrafish. Ecotoxicology 2014, 23, 1854-1857. [CrossRef] [PubMed]

24. Yang, W.K.; Chiang, L.F.; Tan, S.W.; Chen, P.J. Environmentally relevant concentrations of di(2-ethylhexyl) phthalate exposure alter larval growth and locomotion in medaka fish via multiple pathways. Sci. Total. Environ. 2018, 640-641, 512-522. [CrossRef] [PubMed]

25. Zheng, Q.; Feng, M.; Dai, Y. Comparative antioxidant responses in liver of Carassius auratus exposed to phthalates: An integrated biomarker approach. Environ. Toxicol. Pharmacol. 2013, 36, 741-749. [CrossRef]

26. Pecoraro, R.; Marino, F.; Salvaggio, A.; Capparucci, F.; Di Caro, G.; Iaria, C.; Salvo, A.; Rotondo, A.; Tibullo, D.; Guerriero, G.; et al. Evaluation of chronic nanosilver toxicity to adult zebrafish. Front. Physiol. 2017, 8, 1011. [CrossRef]

27. Pecoraro, R.; D’Angelo, D.; Filice, S.; Scalese, S.; Capparucci, F.; Marino, F.; Iaria, C.; Guerriero, G.; Tibullo, D.; Scalisi, E.M.; et al. Toxicity evaluation of graphene oxide and titania loaded nafion membranes in zebrafish. Front. Physiol. 2018, 8, 1039. [CrossRef]

28. Iaria, C.; Migliore, S.; Macri, D.; Bivona, M.; Capparucci, F.; Gaglio, G.; Marino, F. Evidence of Centrocestus formosanus (Nishigori, 1924) in Zebrafish (Danio rerio). Zebrafish 2019, 16, 522-526. [CrossRef]

29. Critchfield, F.E.; Bishop, F.E. Water Determination by Reaction with 2,2-Dimethoxypropane. Anal. Chem. 1961, 33, 1034-1035. [CrossRef]

30. OECD. OECD Guidelines for the Testing of Chemicals. Methods Mol. Biol. 2004, 947, 37-56.

31. Hallare, A.; Nagel, K.; Köhler, H.R.; Triebskorn, R. Comparative embryotoxicity and proteotoxicity of three carrier solvents to zebrafish (Danio rerio) embryos. Ecotoxicol. Environ. Saf. 2006, 63, 378-388. [CrossRef] 
32. Finney, D.J. Probit Analysis; Cambridge University Press: London, UK; New York, NY, USA, 1971; pp. $20-47$.

33. Bradford, M.M. A Rapid and Sensitive Method for the Quantitation of Microgram Quantities of Protein Utilizing the Principle of Protein-Dye Binding. Anal. Biochem. 1976, 72, 248-254. [CrossRef]

34. Beauchamp, C.; Fridovich, I. Superoxide Dismutase: Improved Assays and an Assay Applicable to Acrylamide Gels. Anal. Biochem. 1971, 44, 276-287. [CrossRef]

35. Livingstone, D.R. Oxidative stress in aquatic organisms in relation to pollution and aquaculture. Revue de Medecine Veterinaire 2003, 154, 427-430.

36. Livak, K.J.; Schmittgen, T.D. Analysis of relative gene expression data using real-time quantitative PCR and the 2(-Delta Delta C(T)) Method. Methods 2001, 25, 402-408. [CrossRef]

37. Adams, W.J.; Biddinger, G.R.; Robillard, K.A.; Gorsuch, J.W. A summary of the acute toxicity of 14 phthalate esters to representative aquatic organisms. Ecotoxicol. Environ. Saf. 1995, 14, 1569-1574. [CrossRef]

38. Buccafusco, R.J.; Ells, S.J.; Leblanc, G.A. Acute Toxicity of Priority Pollutants to Bluegill (Lepomis macrochirus). Bull. Environ. Contam. Toxicol. 1981, 26, 446-452. [CrossRef]

39. Rana, K.; Patel, J.; Prasad, B. Effect of an Endocrine-disrupting Chemical Dimethyl Phthalate on Poecilia sphenops. Nat. Environ. Pollut. Technol. 2018, 17, 71-76.

40. Brannen, K.C.; Panzica-Kelly, J.M.; Danberry, T.L.; Augustine-Rauch, K.A. Development of a zebrafish embryo teratogenicity assay and quantitative prediction model. Birth Defects Res. B. Dev. Reprod. Toxicol. 2010, 89, 66-77. [CrossRef]

41. Burridge, L.E.; Haya, K. A Review of Di-n-butylphthalate in the Aquatic Environment: Concerns Regarding Its Use in Salmonid Aquaculture. J. World Aquacult. Soc. 2007, 26, 1-13. [CrossRef]

42. Staples, C.A.; Adams, W.J.; Parkerton, T.F.; Gorsuch, J.W.; Biddinger, G.R.; Reinert, K.H. Aquatic toxicity of eighteen phthalate esters. Environ. Toxicol. Chem. 1997, 16, 875-891. [CrossRef]

43. Martínez-Alvarez, R.M.; Hidalgo, M.C.; Domezain, A.; Morales, A.E.; García-Gallego, M.; Sanz, A. Physiological changes of sturgeon Acipenser nacarii caused by increasing environmental salinity. J. Exp. Biol. 2003, 205 (Pt 23), 3699-3706.

44. Sies, H. Biochemistry of oxidative stress. Angew. Chem. Int. Edit. 1986, 23, 1798. [CrossRef]

45. Fridovich, I. Superoxide Radical and Superoxide Dismutases. Annu. Rev. Biochem. 1995, 64, 97-112. [CrossRef] [PubMed]

46. Arun, S.; Subramanian, P. Antioxidant enzymes activity in subcellular fraction of freshwater prawns $M$. malcolmsonii and M. lamarrei lamarrei. Appl. Biochem. Biotechnol. 1998, 75, 187-192. [CrossRef]

47. Alfadda, A.A.; Sallam, R.M. Reactive Oxygen Species in Health and Disease. J. Biomed. Biotechnol. 2012, 2012, 936486. [CrossRef]

48. Kim, H.; Kim, J.S.; Lee, Y.M. Changes in activity and transcription of antioxidant enzymes and heat shock protein 90 in the water flea, Daphnia magna exposed to mercury. Toxicol. Environ. Health. Sci. 2017, 9, 300-308. [CrossRef]

49. Yokota, H.; Satoh, Y.; Ono, Y.; Kaneko, M.; Ikeda, H.; Tsuji, S.; Yatomi, Y. Establishment of a pharmacogenomic testing system for the realization of individual pharmacotherapy. Rinsho Byori 2008, 56, 772-780.

50. Zhang, C.; Hu, J.; Wang, P. Effects of B(a)P on T-AOC in liver of Carassius auratu. J. Environ. Health. 2004, 5, 324-326. (In Chinese)

51. Bernanke, J.; Köhler, H.R. The Impact of Environmental Chemicals on Wildlife Vertebrates. Rev. Environ. Contam. Toxicol. 2009, 198,1-47.

52. Mather-Mihaich, E.; Di Giulio, R.T. Oxidant, mixed-function oxidase and peroxisomal responses in channel catfish exposed to a bleached kraft mill effluent. Arch. Environ. Contam. Toxicol. 1991, 20, 391-397. [CrossRef]

53. Livingstone, D.R. Contaminant-stimulated reactive oxygen species production and oxidative damage in aquatic organisms. Mar. Pollut. Bull. 2001, 42, 656-666. [CrossRef]

54. Benedetti, M.; Giuliani, M.E.; Regoli, F. Oxidative metabolism of chemical pollutants in marine organisms: Molecular and biochemical biomarkers in environmental toxicology. Ann. N. Y. Acad. Sci. 2015, 1340, 8-19. [CrossRef] [PubMed]

55. Valavanidis, A.; Vlahogianni, T.; Dassenakis, M.; Scoullos, M. Molecular biomarkers of oxidative stress in aquatic organisms in relation to toxic environmental pollutants. Ecotoxicol. Environ. Saf. 2006, 64, 178-189. [CrossRef] [PubMed] 
56. Pedrajas, J.R.; Peinado, J.; Lopez-Barea, J. Purification of Cu, Zn-superoxide dismutase isoenzymes from fish liver: Appearance of new isoforms as a consequence of pollution. Free Radic. Res. Commun. 1993, 19, $29-41$. [CrossRef]

57. Pedrajas, J.R.; Peinado, J.; Lopez-Barea, J. Oxidative stress in fish exposed to model xenobiotics. Oxidatively modified forms of $\mathrm{Cu}, \mathrm{Zn}$-superoxide dismutase as potential biomarkers. Chem. Biol. Interact. 1995, 98, 267-282. [CrossRef]

58. Dorval, J.; Hontela, A. Role of glutathione redox cycle and catalase in defense against oxidative stress induced by endosulfan in adrenocortical cells of rainbow trout (Oncorhynchus mykiss). Toxicol. Appl. Pharmacol. 2003, 192, 191-200. [CrossRef]

59. Dinu, D.; Marinescu, D.; Munteanu, M.C.; Staicu, A.C.; Costache, M.; Dinischiotu, A. Modulatory Effects of Deltamethrin on Antioxidant Defense Mechanisms and Lipid Peroxidation in Carassius auratus gibelio Liver and Intestine. Arch. Environ. Contam. Toxicol. 2010, 58, 757-764. [CrossRef]

(C) 2020 by the authors. Licensee MDPI, Basel, Switzerland. This article is an open access article distributed under the terms and conditions of the Creative Commons Attribution (CC BY) license (http://creativecommons.org/licenses/by/4.0/). 